limitod the use of the method (for the number of abnormal records far exceeds the number of patients with cardiac impairment discernible on any other grounds); or should we maintain faith in the method and creato a new disease of "presbycardia" which can only be detected by ultrasensitive ballistocardiography? The data offered on the long-term follow-up of patients with such abnormal records certainly tend to support the latter view. This may not matter too much at the moment because little can be done to improve such hearts, but this may not always bo the case. Furthermore, there are times when it is important to exclude the slightest hint of cardiac disease (for example, in testing air-lino pilots). It is not made clear in the book whether the ballistocardiogram would be fair for this purpose.

With regard to the follow-up of abnormal records, several examples are shown together with a note of the unfortunate outcome. It may be felt that such anocdotes do not prove anything because normal records might be followed by such an outcome and many abnormal records are not. I feel, however, that there is an advantage in showing such records in order to acquaint the reader with the order of change that might be expected with the method.

One of the most interesting sections of the book deals with the effects of drugs (for example, digitalis and anaesthetics) on eardiac function and this would seem to be a useful area of study. Perhaps too much of the book is devoted to comparing records botween different people and establishing norms as opposed to testing cardiac function by comparing the record in one patient before and during some manoeuvre. Such manoeuvres are technically difficult if they involve the patient leaving the ballisto. cardiography table and then returning. One simple munoeuvre not montioned is the administration of a drug by aerosol during continuous recording.

A point well made by Dr Starr is the importance of the ballistocardiogram in assessing therapy, as in the excellent work done by Dr Deuchar with reference to aortic valve disease and cardiac surgery. The best way the ballistocardiogram can demonstrate its usefulness to unbelievers is in certain definite conditions rather than as a diffuse multi-purpose test.

In the final chapter Dr Starr effectively indicates the place of the ballistocardiogram in medicine and leaves no doubt that with robust instrumentation this method must become accopted as routine. For this reason, and also on its own account, this book belongs in every cardiology department. EDward F. DE Bono

\section{FUNGAL COMMUNITIES}

\section{Ecology of Fungi}

By R. K. Robinson. (Modern Biology Series.) Pp. 116. (London: 'The English Universities Press, Ltd., 1967.) $21 s$. net.

IN these days of increasingly precocious specialization in tho education of scientists, it is becoming ever more important for young biologists not to miss the right choice through sheer ignorance of all the possible alternatives. Dr Robinson's book is a good example of what can bo done in about a hundred pages of text to introduce a beginner to a new field of biology. The fungi, because of their larger cell size and much greater morphological diversity, provide a better introduction to the science of microbial ecology than do either the bacteria or the actinomycetes, so that identification into species is thereby both more rapid and more certain. In this book, Dr Robinson surveys the subject of fungal ecology in four chapters; an introductory one on fungal morphology, organization and classification is followed by others on saprophytic fungi, root-inhabiting fungi, and parasitic fungi, respectively. The book is illustrated by thirty. eight text-figures, some of them original; among the latter, Fig. $20 \mathrm{~B}$ is so unlike its subject (conidia of $\mathrm{Hel}$ minthosporium sativum) as to suggest a mistake in label. ling. Dr Robinson's treatment of his subject in these four chapters is comprehensive and very readable, as well as being thoroughly up to date. He is likely to be widely successful in explaining to young biologists what the science of microbial ecology in general, and of fungal ecology in particular, is about. S. D. GARRE'T

\section{ADVANCED LIMNOLOGY}

\section{A Treatise on Limnology}

By G. Evelyn Hutchinson. Vol. 2: Introduction to Lake Biology and the Limnoplankton. Pp. xi+1,115. (London and New York: John Wiley and Sons, Inc., 1967.) 310s. Ir is just ten yoars since the appearance of the first volume of this treatise, treating the geography, physies and chemistry of lake systems which to many limnologists has been a model of concise scientific writing and a mine of information. This second volume continues the fine tradition although some may be disappointed that it does not complete tho treatise, but the subject has expanded such that productivity of the plankton, nonplanktonic communities, typological, stratigraphic and developmental aspects are left to a third volume. There is no doubt that this was the only solution if the comprohensive coverage of the first volume was to continue through the biological part of the treatise. Let me say at once that this is a most impressive volume, combining as usual in Hutchinson's work an extensive review of the literature with a masterly synthesis of ideas and an original approach to so many aspects. Before the preface is an extract from Hudson and Gosse's classic work on the Rotifera-it is a lyrical passage and typifies Hutchinson's obvious fascination with the natural history of freshwater life. But this book is a natural history carried through to the most rigorous scientific analysis culminating in mathematical models wherever possible.

The opening chapter on the nature and origin of the freshwater biota starts with a synopsis of classification of the plant and animal groups represented in freshwaterit will provoke controversy, as Hutchinson intends. The accent in the discussion of the biota is on the adaptation from the marine to the freshwater environment and on the geological history. The physiological problems of adaptation to freshwater are discussed and the genera illustrated are taken from the world fauna and many obscure forms are illustrated. There is a wealth of fascinating information here, but the reader has to wait until the later chapters for illustrations and discussions of the biology of the commoner plants and animals.

The second chapter is a very brief but valuable account of the terminology of lacustrine communities - the concept of a lake as a single biotope is not strictly adhered to in later chapters and some of the terms are littlo used. A fairly mathematical treatment of the hydromechanics of the plankton follows in which sinking rates and turbulence are considered. The next three chaptors are devoted to the phytoplankton; first its nature and distribution, in which the major algal groups are discussed and related to somo physiological parameters; sccondly, the assuciations including multispecific equilibrium, diversity and ocological classification; moving finally to the seasonal succession in the last of these chapters. The examples are selected from a wide series of lake studies and these have been welded into a coherent story in which the author has not meroly been content to report the work of others but has analysed it and synthesized it into a valuable discussion. The last three chapters are devoted to the animal components of the plankton. The nature and biology of the zooplankton are largely concerned with 